\title{
Mitigating losses: How science diplomacy can address the impact of COVID-19 on early career researchers
}

Sandra Lopez-Verges ${ }^{1}$, Bernardo Urbani ${ }^{2}$, David Fernandez Rivas ${ }^{3}$, Sandeep KaurGhumaan ${ }^{4}$, Anna Coussens ${ }^{5}$, Felix Moronta-Barrios ${ }^{6}$, Suraj Bhattarai ${ }^{7}$, Leila Niamir ${ }^{8}$, Velia Siciliano ${ }^{9}$, Andreea Molnar ${ }^{10}$, Amanda Weltman ${ }^{11}$, Meghnath Dhimal ${ }^{12}$, Shalini S. Arya ${ }^{13}$, Karen J. Cloete ${ }^{14}$, Almas Taj Awan ${ }^{15}$, Chandra Shekhar Sharma ${ }^{16}$, Clarissa Rios Rojas ${ }^{17}$, Yoko Shimpuku ${ }^{18}$, John Ganle ${ }^{19}$, Maryam M. Matin ${ }^{20}$, Nzweundji Justine Germo ${ }^{21}$, Abdeslam Badre ${ }^{22}$, Paulina Carmona-Mora $23 \ddagger$

${ }^{1}$ Gorgas Memorial Institute of Health Studies, Sistema Nacional de Investigación SNI del SENACYT, Panama City, Panama

${ }^{2}$ Center for Anthropology, Venezuelan Institute for Scientific Research, Caracas, Venezuela

${ }^{3}$ University of Twente, Enschede, The Netherlands

${ }^{4}$ University of Delhi, New Delhi, India

${ }^{5}$ Walter and Eliza Hall Institute of Medical Research, Victoria, Australia

${ }^{6}$ International Centre for Genetic Engineering and Biotechnology, Trieste, Italy

${ }^{7}$ Global Institute for Interdisciplinary Studies, Kathmandu, Nepal

${ }^{8}$ Mercator Research Institute on Global Commons and Climate Change, Berlin, Germany

${ }^{9}$ Istituto Italiano di Tecnologia, Naples, Italy

10 Swinburne University of Technology, Melbourne, Australia

${ }^{11}$ University of Cape Town, Cape Town, South Africa,

12 Nepal Health Research Council, Kathmandu, Nepal

${ }^{13}$ Institute of Chemical Technology, Mumbai, India

${ }^{14}$ University of the Western Cape, Cape Town, South Africa

${ }^{15}$ Federal University of São Carlos, São Paulo, Brazil

16 Indian Institute of Technology, Hyderabad, India

${ }^{17}$ Centre for the Study of Existential Risk at the University of Cambridge, Cambridge, United Kingdom

${ }^{18}$ Hiroshima University, Hiroshima, Japan

${ }^{19}$ University of Ghana, Accra, Ghana

20 Department of Biology, Ferdowsi University of Mashhad, Mashhad, Iran

21 Institute of Medical Research and Medicinal Plants Studies, Yaounde, Cameroon

${ }_{22}$ Mohammed 5 University in Rabat, Rabat, Morocco

${ }^{23}$ Department of Neurology and MIND Institute, University of California-Davis, Sacramento, California, USA.

‡ Corresponding author: Paulina Carmona-Mora, PhD pcarmona@ucdavis.edu

* The authors are members or alumni of the Global Young Academy (GYA). 


\section{Introduction}

Despite the failures to tackle early coordinated responses at national and multinational levels $^{1}$, the global emergence of Coronavirus Disease 2019 (COVID-19) pandemic promoted unprecedented actions on the science-policy, science-communication, and science-diplomacy interfaces worldwide. With varying degrees of success, various actions within the realm of science diplomacy have accompanied the creation of knowledge related to COVID-19 through international collaboration 23456 . The COVID-19 pandemic brought the world to a standstill and also drew attention to the genuine need for science diplomacy $\begin{aligned} & 789 \\ & 910\end{aligned}$ highlighted the need of training opportunities in the interface of policy and diplomacy for researchers to be able to get grips on emerging health issues. Moreover, it is necessary to create specific platforms for experts to interact with decision-makers at the national and international levels, especially in the Global South. This crisis inevitably shifted the focus on scientific areas that directly address the pandemic response (epidemiology, public health, virology, immunology, pharmacology, human behavioral research, economics, among others). At the same time, some areas not related to the pandemic response have been slowed down due to inevitable physical and social restrictions that impacted certain aspects of the academic life. This does not only relate to daily access to the lab, scientific collections, or field sites, but also associates with furloughed employees and reduced funding to non-COVID-19-related research ${ }^{11} 121314$. Moreover, during the pandemic, women and (usually young) scientists with children have reduced their research efforts substantially, with future implications still difficult to quantify ${ }^{15}$. While some researchers might have harnessed telecommuting and lockdown periods to focus on data analysis and publication writing, gender bias still exists ${ }^{16} 17$. The slight increase in publications with pre-acquired data may still be followed by an immediate future impacted by the lack of data acquisition during the pandemic. These issues may create longterm effects due to reduced capacity for generating pre-requisite data for securing new funding, termination of research, reduced networking opportunities, restrictions to international collaborations, collectively having a negative impact on other disciplines. While most established researchers may not be affected hardly by the above-mentioned effects, early career researchers (ECRs), represent a more vulnerable population ${ }^{18}$. ECRs usually refer to PhD students, postdoctoral fellows and scientists who have 10 years or less of experience after the doctoral degree, although there is some flexibility in this definition ${ }^{19}$. Due to their career stage, ECRs often face job precarity, lack of available opportunities, low funding, and 
job insecurity 20 (e.g., untenured positions and temporary contract employees). These problems are augmented by the COVID-19 pandemic and may be experienced more in countries with a developing scientific system. The impact could be higher for countries that are developing their research environment, are dependent on training their ECRs and conducting experiments abroad through international exchanges programs ${ }^{21}$, which have been stopped due to the pandemic.

Given these unprecedented times, it has been observed that international scientific organizations, policy-makers, scientific communities, and private stakeholders have strengthened their collaborations in response to the pandemic ${ }^{22}$. We, as ECRs, strongly believe that science diplomacy can make a difference in addressing the challenges (emanated or amplified by the current pandemic) that ECRs would face inside and outside academia. Here we present such challenges, and discuss how the Global Young Academy (GYA), an independent organization of early to mid-career researchers across all disciplines and countries, has provided a platform for ECRs to practice science diplomacy, science advice, and science communication. The former by serving as a bridge between ECRs and governments, the second by hearing the voices of young researchers when enacting policies, and the latter by informing societies about the benefits of scientific research. Motivated by the described examples, we recommend measures for scientists, funding agencies, and international organizations to foster international collaboration in these unparallel times.

\section{Effects of the COVID-19 pandemic on science and early career researchers}

The COVID-19 pandemic has affected science globally at multiple levels and scales ${ }^{23}$. Scientific fields directly related to the pandemic response ${ }^{24}$ received special attention at the national, regional, and global levels in terms of funding priorities, continuity of in-person activities during movement restrictions, as well as public awareness about their relevance to the society. The urgency of the pandemic response prompted the creation of international collaborations (e.g., diagnosis, vaccines and therapeutics development, viral genome sequencing, and clinical trials) all supported with quick calls for special funding opportunities. Another collateral but unexpected effect of the pandemic are enhanced virtual interactions observed across disciplines. Conferences, workshops, and seminars that moved to digital formats often became more inclusive and enabled scientists to potentially reach broader 
audiences. International academic mobility and scientific exchange are commonly threatened by limited travel budget and visa-related issues ${ }^{25}$, then virtual meetings addressed inclusiveness concerns, especially for ECRs from low and middle-income countries. Nevertheless, the lack of in-person interactions may not allow sufficient networking opportunities for the initiation of collaborations, or career opportunities for ECRs, specially outside their countries, often a scientific training step for ECRs from developing countries 2627 28. The positive and negative effects of virtual engagement have been discussed, including inequities in technology access and personal issues associated with telecommuting ${ }^{29}$.

Closures of laboratories, quarantines in many countries, and concomitant travel restrictions stalled progress in research other than COVID-19-related, reasons for many scientists to not attend conferences planned before the pandemic was declared, reducing chances for engaging with other researchers. Additionally, researchers in general need to secure funding, which usually depends on the progress of ongoing research. The issues inherent to the pandemic contingency may not provide the conditions to advance research for securing future funding. This has a higher effect on ECRs whose salaries generally depend directly on their grants or fellowships 3031 . This scenario could be improved if researchers create new partnerships, especially between countries with different management of the COVID-19 contingency, or that are at different stages of the pandemic. Thus, research tasks could be shared and complemented if performed in different locations or sharing facilities where the contingency allows in-person work, as part of a collaboration with researchers where research is stalled, allowing for continuity.

The issues affecting ECRs working in disciplines not directly related to the pandemic response, also worsened the plight of some subgroups, particularly postdoctoral researchers and those finishing their PhDs, impacting career plans, expiration of fellowships, and wellbeing

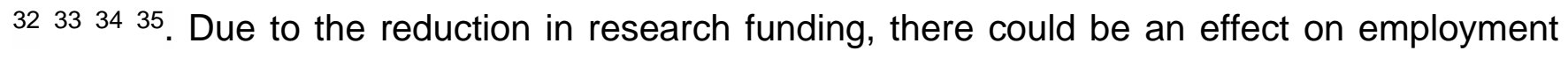
and contract-research workers, a common scenario for ECRs, making them prone to job insecurity. ECRs undergo years of extensive training and undoubtedly, they represent one of the most highly skilled workforces as they continue advancing their careers. The insecurities of scientific careers may discourage postdoctoral researchers and up-coming generations of science graduates from adopting scientific research as a lifelong career or even dropping scientific careers both in academic and private sectors. This may disproportionately affect women, underrepresented groups, and science-lagging countries ${ }^{36}{ }^{37}$. Furthermore, these 
issues would also impact higher education as ECRs have a relevant role in teaching/education, especially at the undergraduate level and the formation of new researchers. Science diplomacy and international organizations could help design international exchange and engagement programs to support ECRs continue their research in the current and post-pandemic times.

\section{An academy of early career researchers as science diplomacy actors}

The GYA is a worldwide organization of early and mid-career scientists from different fields of knowledge. It empowers young researchers to lead international, interdisciplinary, and intergenerational dialogues to create an impact on science and society. GYA has served as a supportive institution promoting the foundation of novel National Young Academies (NYAs) worldwide ${ }^{38}$. In doing so, members of these academies have engaged in debates that served to modulate the pace of diplomatic efforts of their countries from a scientific realm. NYAs have promoted science advice at the national level and science diplomacy and scientific collaboration at the regional level and worldwide, many times with GYA participation ${ }^{39}$.

The World Health Organization declared COVID-19 a pandemic on March 11, 2020. To support the pandemic response, on March 26, the GYA released the statement "Beyond Boundaries: A global message from young scientists on COVID-19", with recommendations to strengthen international partnerships, as well as to formulate harmonized international scientific policies toward the mitigation of the pandemic effects ${ }^{40}$. On the axis Science in Diplomacy, as part of the G7 group of academies, GYA is able to integrate the voices of ECRs with the advocacy of diplomatic groups; as seen with the release of the statement "The critical need for international cooperation during Covid-19 pandemic joint statement of Academies of Sciences and Medicine" ${ }^{41}$. Also, in 2020, the group of G20 Science Academies (S20), created the statement on "Foresight: Science for Navigating Critical Transitions," 42 with participation of GYA members. This communique directly reported to policy-makers and/or governments of G20 countries.

The initial months of the pandemic highlighted the need of inclusive science communication that helps inform and show the population about the need of science diplomacy and science advice to tackle solutions to the pandemic. The webinar "COVID-19 in 
Latin America, perspectives from young scientists" in May 2020, brought together six GYA scientists to provide 132 attendees from 20 countries with reliable and accurate information on the pandemic ${ }^{43}$.

The transition to online interactions created more inclusive settings by eliminating travelassociated logistics and monetary factors as limitations. Often, travel expenses for in-person meetings of academies may not be allocated from research grants or fellowships as they are considered service, hindering participation. The first GYA e-AGM and e-conference (June 2020), combined real-time interactive and asynchronous events, and discussions with prerecorded presentations. This was the year with the highest attendance, despite encompassing attendees challenged by the differences in time zones. But the digital divide, which existed before the pandemic, has surfaced more than ever now that most events are virtual. One aspect is suboptimal or lack of suitable technology in some regions -a major challenge for synchronic engagement. A practical measure to enable equal opportunities for synchronous interactions is to subsidize internet access for participants in a specific event as fees might be prohibitory in some countries ${ }^{44}$. The e-events offered new, experimental ways of engagement for GYA members, representatives of NYAs, renowned scientists, professionals in science policy, along with key partner organizations ${ }^{45}$.

Another aspect of the digital divide is the paywall to access scientific literature and publication fees, which may be aggravated by reduced funding ${ }^{46}$. In fact, it might be worse during the pandemic in institutions with no remote access to their digital library during closures. Interestingly, most of COVID-19-related research has been made open access, evidencing the urgency to advocate for open access for all other disciplines, a trend that must be promoted and expanded. The GYA advocates for open science through partnering with UNESCO and other key stakeholders in a wide range of initiatives ${ }^{47}$.

The GYA and NYAs work together to increase scientific collaborations in different regions and suggest solutions from ECRs to address globally important issues. The global meeting of NYAs, the largest gathering ${ }^{48}$ of young academies so far (and first-ever online) organized by GYA in September 2020, represented a global platform for establishing further collaborations and exchange of best practices. From a science diplomacy perspective, it allowed exchanging ideas between ECRs with different decision-making capabilities within academic, private, and governmental sectors. This meeting served for gathering Latin 
American and Caribbean fellows involved in the writing of a current assessment on the situation of early- and mid-career scholars in this region ${ }^{49}$. A recent GYA-funded report presented a regional assessment on future research perspectives of ECRs from South East Asia ${ }^{50}$. Some major trends were reported: limited intraregional scientific collaboration and mobility, disparities in scientific practices between countries, and lack of proper availability of resources for scientific research.

The GYA's North-South interdisciplinary grants ${ }^{51}$ and the Young Scientist Ambassador Program (YSAP) ${ }^{52}$ are two concrete examples of sustained opportunities that are the direct outcome of interactions created as part of the membership to GYA. These annual projects create deliverables that enable further joint projects ${ }^{53}$. The nature of these programs is to connect researchers across countries that do not traditionally engage through science. A key inclusive factor, since cultural or regional conditions may represent biases that forbid researchers from establishing novel partnerships. These collaborations may also involve outreach programs and interactions with stakeholders (e.g., media, policy-makers), increasing the impact and fostering science diplomacy through scientific collaboration ${ }^{54}$. In 2020 , the bilateral YSAP missions were modified to a virtual format, time will determine if their impact is similar to the in-person format ${ }^{55}$. The North-South grant aims to foster global collaboration within the GYA. For 2020/21, it was awarded to members from six countries, who aim to collect, and analyze the artwork of life during the COVID-19 pandemic across the world in relation to the measured intensity of the pandemic ${ }^{56}$.

To suggest tailored solutions, further effects of the pandemic on ECRs must be assessed. Members of the GYA Women in Science working group compiled experiences amongst members, women scientists from different countries, as they tried to navigate their work and motherhood. They shared pieces of advice and motivation in the article "GYA Women in Science stay and work from home: How might we make COVID-19 lockdown work for us?" 57 . This exploratory perspective was applied to other projects, like the inclusion of COVID-19-related questions in different surveys, such as the impact of the pandemic in women in science's work, or on ECRs from a specific region through the Global State of Young Scientists in Latin America and the Caribbean study (GLoSYS LAC). To understand the role of science and ECRs in the current pandemic, other GYA surveys about trust in medical science or young scientists' perception on science advice were updated as well. The results of these 
studies will be presented to policy-makers and are expected to be used to improve the environment in which ECRs develop their missions.

Capacity building for global partnerships is crucial all the time, but even more necessary in these times that science needs collaborative young leaders with science communication, advice and diplomacy skills. The Science Leadership Programs (SLPs) implemented by GYA in Africa and Asia, are tools that could be adapted for current specific needs and be expanded to other regions. Additionally, a specific space to harness science diplomacy skills of ECRs in South Asia was developed as a virtual workshop ${ }^{58}$.

\section{Recommendations to support early career researchers affected by the pandemic}

A global perspective on the issues emerging from the COVID-19 pandemic contingency and impact on ECRs have been presented. There is a need to develop strategies to boost scientific diplomacy to solve these challenges. Relevant GYA activities have been introduced, constituting experiences on how international associations can foster partnerships to enable science diplomacy to act proactively. Similarly, the support of the recommendations listed below might be useful and considered as intersectional issues that can be developed in future science diplomacy engagements. Based on this, relevant recommendations are proposed and can be extrapolated in other settings, for scientists and policy-makers to employ science diplomacy tools to address and overcome these urgent issues. 


\begin{tabular}{ll} 
Challenge & Recommendation \\
\hline & For young researchers: \\
& Connect digitally with \\
& other researchers, \\
& regionally and globally. \\
& Membership to a relevant \\
& organization to facilitate \\
& asynchronous interactions \\
& with a wide array of \\
colleagues
\end{tabular}

Reduced visibility and networking opportunities for ECRs

\section{Goal}

New opportunities
for partnerships to
increase
collaborations and
competitiveness,
fostering technical
exchange and
scientific
excellence

experience and create bridges of mentoring and collaborations
Measures of success

\section{Research}

output

(publications,

briefings, etc.)

metrics, funding

adjudication, broader impact

of research
Science diplomacy component

Promotion of intergovernmental associations for fostering mobility of researchers between countries
For international Facilitate the societies, academies, and transfer of organizations:

Establish/enhance mentoring programs (at the intergenerational and international levels)
Acquisition of leadership skills, case by case on novel professional development opportunities and new collaborations

International societies,
academies, and
organizations: create
capacity building
opportunities to empower
leadership

Increased

visibility and representation of ECRs in science advice and diplomacy

Access to a highly skilled scientific workforce to work together in the interphases of policy and diplomacy with regional or global perspective

\begin{tabular}{|c|c|}
\hline $\begin{array}{l}\text { Reduction of } \\
\text { international } \\
\text { collaborations, } \\
\text { especially for } \\
\text { science- } \\
\text { lagging or } \\
\text { ODA recipient } \\
\text { countries }\end{array}$ & $\begin{array}{l}\text { Funding agencies: } \\
\text { enhance or create funding } \\
\text { that allows the creation of } \\
\text { new collaborative } \\
\text { projects, including pilots } \\
\text { and, exploratory studies } \\
\text { opened to applicants from } \\
\text { all professional stages. } \\
\text { Encourage the inclusion } \\
\text { of science-lagging } \\
\text { countries in international } \\
\text { consortiums. Flexibility in } \\
\text { timelines and extension } \\
\text { supplements for active } \\
\text { proiects }\end{array}$ \\
\hline
\end{tabular}

\section{Connect countries}

through science by creating global fellowships for ECRs to establish new collaborations and continue their research, or gather preliminary data to secure future funding
Furthering the circulation of scientific experiences at multinational levels, with focus in less developed countries
Facilitate tailored programs for creating coherent policies to avoid brain drain and loss, and stimulate innovation by young researchers

\begin{tabular}{|c|c|}
\hline $\begin{array}{l}\text { Research } \\
\text { output } \\
\text { (publications, } \\
\text { briefings, etc.) } \\
\text { metrics, funding } \\
\text { acquisition, } \\
\text { successful } \\
\text { continuity of } \\
\text { ongoing } \\
\text { projects. } \\
\text { broader impact } \\
\text { of research }\end{array}$ & $\begin{array}{l}\text { Implement } \\
\text { collaborative } \\
\text { scientific schemes } \\
\text { with national, } \\
\text { regional, and } \\
\text { transnational } \\
\text { stakeholders to } \\
\text { promote scientific } \\
\text { exchange }\end{array}$ \\
\hline
\end{tabular}




\begin{tabular}{|c|c|c|c|c|}
\hline $\begin{array}{l}\text { Augmented } \\
\text { impact on } \\
\text { science- } \\
\text { lagging or } \\
\text { ODA-recipient } \\
\text { countries' } \\
\text { ECRs }\end{array}$ & $\begin{array}{l}\text { International societies, } \\
\text { academies, and } \\
\text { organizations: organize } \\
\text { activities that foster a } \\
\text { collaborative and } \\
\text { inclusive environment for } \\
\text { ECRs, allowing equal } \\
\text { engagement and direct } \\
\text { interaction (by } \\
\text { considering technology } \\
\text { access and country } \\
\text { representation) }\end{array}$ & $\begin{array}{l}\text { Empower new } \\
\text { collaborations in } \\
\text { an inclusive } \\
\text { manner, especially } \\
\text { considering } \\
\text { interactions } \\
\text { between the global } \\
\text { North/South and } \\
\text { by fostering } \\
\text { South/South } \\
\text { interconnections }\end{array}$ & $\begin{array}{l}\text { Research } \\
\text { output } \\
\text { (publications, } \\
\text { briefings, etc.) } \\
\text { metrics, funding } \\
\text { acquisition, } \\
\text { representation } \\
\text { metrics per } \\
\text { country/region }\end{array}$ & $\begin{array}{l}\text { Promote regional } \\
\text { and transnational } \\
\text { funding programs to } \\
\text { stimulate hands-on } \\
\text { cooperation } \\
\text { between scientists }\end{array}$ \\
\hline $\begin{array}{l}\text { Understanding } \\
\text { impact of } \\
\text { COVID-19 on } \\
\text { ECRs }\end{array}$ & $\begin{array}{l}\text { International societies, } \\
\text { academies, and } \\
\text { organizations: consider } \\
\text { subsidizing internet } \\
\text { access to members and } \\
\text { create small funding } \\
\text { programs }\end{array}$ & $\begin{array}{l}\text { Increase virtual } \\
\text { engagement }\end{array}$ & $\begin{array}{l}\text { Metrics on } \\
\text { participation } \\
\text { and } \\
\text { demographics, } \\
\text { assessment of } \\
\text { newly created } \\
\text { programs for } \\
\text { ECR } \\
\text { development }\end{array}$ & $\begin{array}{l}\text { Fostering } \\
\text { multinational } \\
\text { investment } \\
\text { allocation in projects } \\
\text { directed by young } \\
\text { researchers }\end{array}$ \\
\hline $\begin{array}{l}\text { Reduction of } \\
\text { funding } \\
\text { impacting } \\
\text { professional } \\
\text { networking } \\
\text { activities }\end{array}$ & $\begin{array}{l}\text { Conference, workshop, } \\
\text { webinar, and event } \\
\text { organizers: hold events } \\
\text { when possible free of } \\
\text { charge or with } \\
\text { low/differential cost to } \\
\text { science-lagging countries; } \\
\text { open the event for all } \\
\text { sectors (academia, } \\
\text { industry, business, } \\
\text { policy); learn from best } \\
\text { practices }\end{array}$ & $\begin{array}{l}\text { Support open } \\
\text { science for all; } \\
\text { increase sectors } \\
\text { engagement; } \\
\text { support science- } \\
\text { policy and science- } \\
\text { stakeholders } \\
\text { discourse }\end{array}$ & $\begin{array}{l}\text { Metrics on } \\
\text { participation } \\
\text { and } \\
\text { demographics }\end{array}$ & $\begin{array}{l}\text { Promote (a) } \\
\text { scientific mobility to } \\
\text { international and } \\
\text { intraregional loci; } \\
\text { and (b) scientific } \\
\text { regular virtual } \\
\text { meetings between } \\
\text { scientists and other } \\
\text { stakeholders (this } \\
\text { kind of meetings is a } \\
\text { pandemic } \\
\text { response/practice } \\
\text { that likely will } \\
\text { remain in the future) }\end{array}$ \\
\hline $\begin{array}{l}\text { Reduction in } \\
\text { scientific } \\
\text { funding }\end{array}$ & $\begin{array}{l}\text { International societies, } \\
\text { academies, and } \\
\text { organizations: advocate } \\
\text { with governments and } \\
\text { institutions to present the } \\
\text { importance of other fields } \\
\text { of science despite the } \\
\text { international emergency } \\
\text { we are facing and aim to } \\
\text { influence public budget } \\
\text { decisions }\end{array}$ & $\begin{array}{l}\text { Mitigate effect on } \\
\text { future funding and } \\
\text { influence decision- } \\
\text { making on current } \\
\text { funding calls. }\end{array}$ & $\begin{array}{l}\text { Changes in } \\
\text { budget } \\
\text { allocation, } \\
\text { incorporation of } \\
\text { new actors in } \\
\text { the funding } \\
\text { landscape, such } \\
\text { as NGOs and } \\
\text { philanthropic } \\
\text { groups }\end{array}$ & $\begin{array}{l}\text { Engaging in regional } \\
\text { legislations (a) to } \\
\text { ensure common } \\
\text { minimum GDPs } \\
\text { amounts for funding } \\
\text { science and reduce } \\
\text { regional scientific } \\
\text { budgetary } \\
\text { differences and } \\
\text { gaps, and (b) to } \\
\text { promote private } \\
\text { investment in } \\
\text { science allied with } \\
\text { academia }\end{array}$ \\
\hline
\end{tabular}


Table 1. Recommendations to create and/or maintain a scientific environment that can foster new international opportunities for ECRs to allow research continuity during and postpandemic. The challenges identified in the first column, represent those originated or augmented by the COVID-19 pandemic. ODA: Official development assistance.

\section{Acknowledgements.}

We would like to thank the GYA Office staff for their instrumental support of the activities presented here and draft review of this article. We appreciate the constructive comments of the editor and the reviewers on an earlier version of this article. The GYA receives core funding from the German Federal Ministry of Education and Research, as well as project funding from a variety of international and national sources.

\section{Endnotes}

${ }^{1}$ E. William Colglazier, America's Science Policy and Science Diplomacy After COVID-19 Science \& Diplomacy, Volume 9, Number. 2, June 2020

https://doi.org/10.1093/bioinformatics/bty407http://sciencediplomacy.org/editorial/2020/america s-science-policy-and-science-diplomacy-after-covid-19

2 https://www.who.int/publications/m/item/draft-landscape-of-covid-19-candidate-vaccines

${ }^{3}$ https://www.who.int/publications/m/item/access-to-covid-19-tools-(act)-accelerator

${ }^{4}$ J. Hadfield, C. Megill, S. M. Bell, J. Huddleston, B. Potter, C. Callender, P. Sagulenko, T. Bedford, R. A. Neher, Nextstrain: real-time tracking of pathogen evolution, Bioinformatics, Volume 34, Issue 23, 01 December 2018, Pages 4121-4123,

https://doi.org/10.1093/bioinformatics/bty407

${ }^{5}$ https://www.covidclinical.net/members/index.html

${ }^{6}$ Y. Zhou, F. Wang, J. Tang, R. Nussinov, F. Cheng. Artificial intelligence in COVID-19 drug repurposing. Lancet Digit Health. 2020 Sep 18. doi: 10.1016/S2589-7500(20)30192-8.

${ }^{7}$ B. Pisupati, Science Diplomacy: COVID-19 and Beyond, Special Issue on COVID-19 Volume 16, No.4 - April 2020

http://ris.org.in/newsletter/diary/2020/Covid\%2019\%20III/pdf/Balakrishna\%20Pisupati.pdf

8 New frontiers in science diplomacy, The Royal Society, January 2010 RS1619. ISBN: 978-085403-811-4 
${ }^{9}$ M.L. Gore, E.S. Nichols, K.R. Lips. Preparing Scientists for Science Diplomacy Requires New Science Policy Bridges. Hague J Dipl 2020; 15: 424-434.

10 https://www.weforum.org/agenda/2020/05/here-s-how-science-diplomacy-can-help-us-

\section{contain-covid-19/}

${ }^{11}$ Boosting research without supporting universities is wrong-headed. Nature 582, 313-314 (2020) doi: 10.1038/d41586-020-01788-6

12 S. H. Subramanya, B. Lama, K.P. Acharya. Impact of COVID-19 pandemic on the scientific community. Qatar medical journal, 2020(1), 21. https://doi.org/10.5339/qmj.2020.21

${ }^{13}$ D.G. Kent, D.J.H.F. Knapp, N. Kannan. Survey Says: "COVID-19 Lockdown Hits Young Faculty and Clinical Trials". Stem Cell Reports. 2020 Jul 14;15(1):1-5. doi:

10.1016/j.stemcr.2020.06.010.

${ }^{14}$ E.g., R.T. Corlett, R.B. Primack, V. Devictor, et al. Impacts of the coronavirus pandemic on biodiversity conservation. Biol Conserv. (2020); 246: 108571.

doi:10.1016/j.biocon.2020.108571

${ }^{15}$ K.R. Myers, W.Y. Tham, Y. Yin. et al. Unequal effects of the COVID-19 pandemic on scientists. Nat Hum Behav 4, 880-883 (2020). https://doi.org/10.1038/s41562-020-0921-y; C. Bittante, G. Beatrice, L. Carletti, A. Mantovani. Gender disparity in authorships of manuscripts on the COVID-19 outbreak [published online ahead of print, 2020 Jun 5]. Z Gesundh Wiss. 2020;1-2. doi:10.1007/s10389-020-01323-x

${ }^{16}$ Nature 581, 365-366 (2020) doi: https://doi.org/10.1038/d41586-020-01294-9

17 M. Oleschuk. (2020), Gender Equity Considerations for Tenure and Promotion during COVID-19. Canadian Review of Sociology/Revue Canadienne de Sociologie, 57: 502-515. https://doi.org/10.1111/cars.12295

18 J.O. Korbel, O. Stegle. Effects of the COVID-19 pandemic on life scientists. Genome Biol 21, 113 (2020). https://doi.org/10.1186/s13059-020-02031-1

${ }^{19}$ P. Bazeley. Defining 'Early Career' in Research. Higher Education 45, 257-279 (2003). https://doi.org/10.1023/A:1022698529612

20 M. Oleschuk. Gender Equity Considerations for Tenure and Promotion during COVID-19. Can. Rev. Sociol. (2020), 57: 502-515. https://doi.org/10.1111/cars.12295

${ }^{21}$ Some of these programs have been developed through science diplomacy by the participating countries with the vision of "diplomacy for science" like the CYTED networks for 
the Iberoamerican region https://www.segib.org/programa/cyted-programa-iberoamericano-deciencia-y-tecnologia-para-el-desarrollo/

22 J. Nicholas Ziegler; Science, Politics, and the Pandemic. Current History 20 October 2020; 119 (820): 303-309. doi: https://doi.org/10.1525/curh.2020.119.820.303

${ }^{23}$ These include academia, transnational stakeholders, governmental agencies, non-state actors, and industries.

${ }^{24}$ As mentioned earlier, disciplines that inform the pandemic response include epidemiology, virology, statistics, immunology, public health and to some degree social sciences, among others.

${ }^{25}$ Nature 563, 7 (2018) doi: https://doi.org/10.1038/d41586-018-07179-2

${ }^{26}$ C.M. Termini, D. Traver. Impact of COVID-19 on early career scientists: an optimistic guide for the future. BMC Biol. 2020 Jul 30;18(1):95. doi: 10.1186/s12915-020-00821-4

${ }^{27} \mathrm{~N}$. Fleming. What's on the agenda for post-pandemic meetings? doi: 10.1038/d41586-02002254-Z

${ }^{28}$ F. Porpiglia, E. Checcucci, R. Autorino, D. Amparore, M. R. Cooperberg, V. Ficarra, G. Novara, Traditional and Virtual Congress Meetings During the COVID-19 Pandemic and the Post-COVID-19 Era: Is it Time to Change the Paradigm?, European Urology, Volume 78, Issue 3, 2020, 301-303

29 The effect of telecommuting with young children at home is only one example of how COVID-19 pandemic has widened gender disparities for women scientists, for senior researchers and more vulnerable ECRs alike. V. Gewin, The career cost of COVID-19 to female researchers, and how science should respond. Nature 583, 867-869 (2020) doi: 10.1038/d41586-020-02183-x. G. Muric, K. Lerman, E. Ferrara, COVID-19 amplifies gender disparities in research arXiv:2006.06142

30 O. Bégin-Caouette, J Jansson, A. Beaupré-Lavallée. The Perceived Contribution of EarlyCareer Researchers to Research Production in Nordic Higher Education Systems. High Educ Policy (2018). https://doi.org/10.1057/s41307-018-0125-5

31 Introductions to the Community: Early-Career Researchers in the Time of COVID-19. Cell Stem Cell. 2020 Jul 2;27(1):13-14. doi: 10.1016/j.stem.2020.06.011 32 Postdocs in crisis: science cannot risk losing the next generation. Nature 2020; 585: 160. 33 J. R. Paula. Lockdowns due to COVID-19 threaten PhD students' and early-career researchers' careers. Nat Ecol Evol 4, 999 (2020). https://doi.org/10.1038/s41559-020-1231-5 
${ }^{34}$ https://www.science.org.au/files/userfiles/support/documents/covid19-emcr-impact-report.pdf ${ }^{35}$ https://www.hepi.ac.uk/2020/03/16/what-might-covid-19-mean-for-phd-students-postdocs/ ${ }^{36}$ K.R. Myers, W.Y. Tham, Y. Yin. et al. Unequal effects of the COVID-19 pandemic on scientists. Nat Hum Behav 4, 880-883 (2020). https://doi.org/10.1038/s41562-020-0921-y ${ }^{37}$ R. Perez Ortega, L. Wessel. 'We're losing an entire generation of scientists.' COVID-19's economic toll hits Latin America hard. doi:10.1126/science.abe2995 ${ }^{38}$ With the support and/or communication with the GYA, NYAs were established in different regions, such as Bangladesh, Hungary, and D.R. Congo. For example, the new D. R. Congo Young Academy of Sciences (DRC-YAS) was supported by the GYA in conjunction with other established African NYAs https://globalyoungacademy.net/congo-young-academy-of-scienceslaunched/

${ }^{39}$ Recently, Young Academies Science Advice Structure (YASAS) was established and the GYA provides an administrative role and acts as executive board member.

https://yacadeuro.org/press-release-fourteen-young-academies-in-europe-prepare-to-deliverscience-advice/

40 Global Young Academy. (2020, March 26). Beyond Boundaries: a global message from young scientists on COVID-19. http://doi.org/10.5281/zenodo.3727699

${ }^{41}$ https://globalyoungacademy.net/gscience-gya-covid-19-statement/

42 This statement provides recommendations on how we navigate the crisis and transition, as a global catastrophe can affect multiple aspects of our lives, such as economies, health and social security systems, access to digital technologies and capacities to respond with robust scientific knowledge to guide national, regional, and global policies, see https://council.science/wp-content/uploads/2020/11/2020 S20SACommunique.pdf ${ }^{43}$ https://globalyoungacademy.net/covid-19-in-latin-america-perspectives-from-youngscientists-webinar-report/

44 The GYA provided such a subsidy for connecting to the e-AGM 2020 in cases where members required it.

${ }^{45}$ https://globalyoungacademy.net/2020-emeetings-healtheearth/

46 The relationship between digital divide and scientific practices is a relevant issue to be tackled as a post-pandemic challenge. 
47 This rapport includes workshops, consultations, and participation in high level dialogues. https://en.unesco.org/news/global-young-academy-contributes-unescos-consultation-openscience

${ }^{48}$ Almost 70 representatives from over 40 young academies gathered at this meeting.

49 Such report is planned to be distributed to various stakeholders in this region with different degrees of decision-making competences. For the ASEAN region, a similar report has been already produced and distributed to different stakeholders See: J. Geffers, C. Beaudry, H-C. Yang, F. Huang, O. Phanraksa, M. Dominik, Y-C. Lin, M-C. Huang, S. Komai, K. Lorimer, W. Piyawattanametha, P. Saengchantr, H. Saleh, B. Tagg and Veerakumarasivam. (2017). Global State of Young Scientists (GloSYS) in ASEAN - Creativity and Innovation of Young Scientists in ASEAN. Global Young Academy. https://globalyoungacademy.net/wp-

content/uploads/2017/01/GloSYS-in-ASEAN webversion.pdf 50 Ibidem.

51 https://globalyoungacademy.net/activities/interdisciplinary-grant-2020-21-the-covid-19pandemic-and-art/

52 https://globalyoungacademy.net/activities/young-scientist-ambassador-program/ ${ }^{53}$ Both programs (North-South grants and YSAP) have allowed to develop further projects, involving publications, graduate student co-supervision and organization of further events, such as conferences. https://globalyoungacademy.net/activities/connecting-epigenetics-andnatural-resources/, https://globalyoungacademy.net/wpcontent/uploads/2017/09/YSAP Mission-Report -Ghada.pdf, https://globalyoungacademy.net/wp-content/uploads/2020/06/YSAP-Mission -Morocco Chile2019.pdf

54 For example, YSAP 2019 mission of climate change and SDGs between Chile and Morocco, included meetings with the respective embassies, outreach in universities, collaborative research and organization of conferences.

${ }^{55}$ As this is a recent program, anecdotal data support the contention that this endeavor set out networks that are currently, - and likely in the future - producing research outputs in the form of reports and peer-reviewed publications.

${ }^{56}$ https://sites.google.com/view/19andart

57 https://globalyoungacademy.net/wp-content/uploads/2020/05/GYA-WiS-Paper-May2020.pdf - This open-access booklet was introduced at the S20 Women in Science webinar (G20 
Science Summit) in September 2020: https://globalyoungacademy.net/gya-members-helpshape-the-g20-science-20-summit/

58 The Science Diplomacy in South Asia workshop had participants from 7/8 South Asian countries. Remarkably, not only in this event but in the organizing working group India and Pakistan are represented, stressing the need and willingness of science in/for diplomacy between countries with recent and current political tensions.

https://globalyoungacademy.net/call-science-diplomacy-for-asia-workshop/ 